\title{
OPEN INNOVATION IN THE PERFORMING ARTS: EXAMPLES FROM CONTEMPORARY DANCE AND THEATRE PRODUCTION
}

\author{
JULIANNA FALUDI ${ }^{1}$
}

\begin{abstract}
Scholarly work about open innovation examines the different components of opening up the innovation process of firms, where the most important feature is sourcing in knowledge. In this paper I examine the implications of adapting an open innovation frame to a field in which it has not been investigated before: the performing arts (contemporary dance and theatre). I draw on case studies and demonstrate that open innovation strategies are viable for use in artistic production. Independent companies purposefully mine external knowledge in production and commercialize on the spillovers of their body of knowledge, putting themselves in the category of firms who are adopting and adapting to open innovation.
\end{abstract}

KEYWORDS: open innovation, cultural production, performing arts, collaborative co-creation, intimacy

\section{INTRODUCTION}

The arts challenge scholars in many ways. First, patterns of arts consumption show peculiarities that derive from the societal dimension of the consumer valuation of artifacts. This fact has been extensively explored by scholars who have created a body of theoretical and empirical literature coined 'the sociology of art' (with explicit and implicit reference to Bourdieu 1993). Second, when investigating the production side of arts, scholars have focused on the implications of the peculiarities of valuing artifacts on production

1 Julianna Faludi is Ph.D. candidate at the Sociology Doctoral School, Corvinus University Budapest, and Trento University, Local Development and Global Dynamics program; e-mail: faludisociology@gmail.com 
(Peterson 2000, DiMaggio 2004, Becker 1982, etc.), and the reasons why multifaceted financial structures support production costs. In this later strand, through focusing on performing arts, cultural economics has analyzed the gap between revenue and expenditure in the performing arts, arguing for dependency and cost-disease (Hansman 1981, Baumol and Bowen 1968, Cowen and Grier 1996, Besharov 2003, Lust and Wetzel 2011). However, despite the existence of some valuable research into larger institutions of cultural production, little is known about innovation in theatrical production from close up.

Innovation aims at creating value, where "value is a measure of an artifact's worth in a particular social context." (Baldwin and Clark 2000, p. 96). Through value creation the artifact embodies what is perceived by the producer to be valued by the audience. Clearly, this paper does not attempt to tackle either consumption or the societal realm of value creation in artistic production; it instead focuses on production and the forces behind innovation that fit into the creative - or more specifically, the cultural industries - frame (Hirsch 1972, 2000).

Despite the vast literature about measuring innovation (through technological, qualitative change or dynamics in capabilities), art production throws a further challenge in the face of scholars. In this realm, in the search for the drivers of innovation in art production we have learned that environmental and organizational characteristics predict innovation activity of theatres (DiMaggio and Sternberg 1985). It has been documented that stylistic innovation presides over technological in the production of (pop) music, toys and games (Caves 2000). A set of indicators has been used to describe the innovation of the National Theatre and the Tate Gallery (Bakhshi and Throsby 2010). Furthermore, there is evidence about the interplay that occurs between the size of the organization, innovation activity and performance on a wide sample of museums (Camarero, Garrido and Vicente 2011). However, little is known from close-up about how new solutions are created during the design of an artifact.

Scholarship on open innovation in the creative industries concentrates on examining networks and the flexibility of organizations that underpin projects. We know that creative work spans organizational boundaries (Grabher 2004). The fact that project-based organizations pool expertise and target deadlines has been explored (Moraga 2006), while they offer face-to-face interaction, nested in an urban space (Lange et al. 2008). Finally, individuals play a leading role in gluing organizations (actors in filming, Baker and Faulkner 1991, through Davis 2005). Apart from analyzing the organizational borders of project-based formations, the efficiency of cultural projects is effectively 
explained by their networks (Staber 2008, Sedita 2008). A further strand of research explores open collaborative innovation in co-creation (Potts et al 2008), and inter-industry linkages (Huage and Hracs 2010, Dell'Era 2010). Forms of open innovation may be spotted in the digital media in open source projects (Aitamurto and Lewis 2012, Lewis and Usher 2013). However, in respect of the performing arts, scholarly work about open innovation is still lacking evidence.

This paper addresses the above-described gaps in the literature by going beyond the broadening the scope of the investigation (on creative industries, tangible products services) by providing empirical findings about cultural production in the performing arts. The case studies presented and analyzed here illustrate the explanatory force of the theoretical framework of open innovation. I specifically focus on the practices of sourcing in knowledge through collaborations that are driven by the producer (note: the director, the creator) of the performance. The findings presented in this paper are part of a broader study that explores innovation patterns in the performing arts (contemporary dance and theatre), and organizational arrangements that are fostering the experimental behavior of independent companies that are present in Budapest, Hungary 2 .

The empirical sections of the paper are organized around the central research questions: how exactly do companies use external knowledge while developing their new performances, and how does such sourcing in evolve into a strategy or business model? I rely on case studies to illustrate the phenomenon under analysis and to reveal a process in time (Siggelkow 2007). As atypical cases offer opportunities for learning (Stake 2003, p. 152), I did not seek out the general, but rather focused on identifying various cases to capture different models. Narrative interviews and (participant) observation helped me to identify innovation strategies to grab examples from. First-hand sources include unstructured, in-depth and semi-structured interviews collected in two waves: from artists and cultural mediators (performers - actors and dancers -, managers, theatre/venue and company directors), and critics (totaling 30 interviews). This research benefits from an holistic understanding of the field, following the traditions of Weber who "proposed two types of understanding: direct observational understanding, and explanatory or motivational understanding" (Ritchie and Lewis 2010, p. 7). I collected data from second-hand sources as well: program leaflets and reviews and interviews published in the (performing arts) press to examine cases. Clearly, there are further examples from the field which have not been

2 Some of the findings are based on an earlier manuscript, Faludi 2012 
included into the current analysis. The purpose of this paper is to shed light on some concurrent cases as an illustration.

\section{BACKGROUND}

Innovation is the process of developing new solutions to defined problems. The knowledge of a group of people fosters finding new solutions. This knowledge involves the coordination of an ever-wider range of disciplines embodied in systems and artifacts (Brusoni et al. 2007). Innovation embraces the search and development of new markets, which is encompassed by the activity of performing arts companies. Performance is an artifact, a set of variations on a set of design rules. It is a product of the project-based organization of artists. Furthermore, it is an interface for intimacy and collaboration patterns. Design is a set of rules that defines the architecture (Baldwin and von Hippel 2011) of a performance. The producer provides the audience with a performance (a good) and expects to benefit by selling the design or the good (here the director/ choreographer).

In terms of theatrical productions independent companies are those that are not tied exclusively to established theatre venues that are sustained directly by public and local authorities, but those which play within the walls of a range of venues, and are sustained indirectly by state or other international art funding agency grants they apply for. The main financial grants cover the costs of overheads, and projects. Project-based grants (with evaluation criteria that request a certain size of audience and frequency of performances) push independent companies toward constantly producing new performances.

Performances compete for venues on the one hand as intangible products, or as the results of projects on the other. Although it is disputed whether new performances are innovations at all in the artistic discourse, I examine the efforts that have been made to find new ways to arrive at a performance from the perspective of production. Furthermore, companies are struggling to gain legitimacy as a survival strategy, while audience-development and establishing closer ties with the public are important tools that may be fostered by the strategy of revealing and opening up production. Pieces throw up more or less complex problems, which must be coped with in terms of staging, and the research and development of solutions takes time and effort. During these efforts companies rely on their internal capacities and previous experience but they may also source in external knowledge from: 1. suppliers and customers; 2. universities and governments; 3. competitors; 4. other nations (following von Hippel 1988); and (I here stretch Von Hippel's frame by adding) 5. field; 
6. community; and 7. local sites and spaces. Most frequently, the director selects from a range of ideas that emerge from different layers of inspiration and elaborates it into a performance, going along a path of research and development that I will explain in the forthcoming sections.

Scholarship on open innovation can be broken into four main strands (as mapped and analyzed in Faludi 2014):

1. the user-oriented approach: where users of the product (service, etc.) provide with solutions to the producer and get involved in the development, pre-commercial use and spread of the solution to different extents (scholarship deriving from von Hippel 1976, 1988, 2005)

2. the producer-driven model: where the producer seeks for external knowledge to source in adapting a business model fostering sourcing in (scholarship deriving from Chesbrough 2006)

3. Networks and ties of firms that benefit from knowledge-sharing

4. Scholarship on collaboration of firms or users: the focus falls on interaction and incentives for co-creation.

In the empirical section of this paper I rely on the producer-driven open innovation model, thus the locus of innovation is the producer (in staging and developing the performance) and collaborators are invited to participate as a source of valuable knowledge. Interaction is thus structured by the conception of the director and collaborative efforts address the task of creating a joint architecture of meanings. However, I suggest that a performance serves as an interface between an audience and the artists in creating meanings. Accordingly, in this investigation I rely on the perspective of the productionside and consider only interaction with the audience that is restricted to the perspective of the producer in the co-creation process.

Scholars have shed light on how firms follow different strategies of openness within their lifetimes. There is evidence that the strategy of opening up is a graduated process and firms may be positioned anywhere between 'open' and 'closed'. External knowledge enters in at different stages of production to firms with various characteristics (Van de Vrande et al 2009, Chiaroni et al 2011, Dahlander and Gann 2010, Barge-Gil 2010). Similarly, in artistic production companies/directors might rely on external sources to enhance the variation of ideas and the meanings created while designing the architecture of a performance.

Open innovation contributes to expanding avenues to market by adding external paths to preexisting internal paths. Due to the eligibility criteria of the grant schemes and the need to gain and enforce legitimacy in the field, independent companies have an indirect interest in the number of viewers and building a reliable audience. The market for theatrical production therefore 
'trades' using performances involving venues, managers, companies and artists.

The importance of external knowledge in innovation and how the role of absorptive capacity (Cohen and Levinthal 1990) defines the extent to which external knowledge can contribute have been examined. Absorptive capacity refers to the firm's ability to acquire, value, assimilate and apply new knowledge. To raise absorptive capacity, firms need to consider increasing their capabilities. It is no less important to consider both internal and external paths to market, which can be extended by opening up a firm. Furthermore, open innovation also means revealing the results of $\mathrm{R} \& \mathrm{D}$ to external players in order to profit from R\&D ideas not elaborated by the firm.

\section{INNOVATION OPENNESS IN THE PERFORMING ARTS: TOWARDS A PRODUCER MODEL?}

The user model suggests that the user enters the innovation process at some stage, invents and creates a prototype and carries out pre-commercial replication or use of the good (von Hippel 1976), or shares it with a community of other users (Füller, Scholl and von Hippel 2013). User-led innovation patterns have been documented in the media as well (Potts et al. 2008). What is distinctive about users is that they directly benefit from their innovation, and they cannot compete with the profits (wider recognition, etc.) gained by producers who provide the product to many users (Faludi 2014, with reference to von Hippel 1998, 2005). The user benefits from the use / consumption of the product.

Users (the audience) might contribute to the creation of the performance while still acting according to the design rules set up previously, allowing direct interaction between audience and performers. Participatory forms of staging are still producer-driven, even if members of audience enter the scene or make a choice about a sequence of acts (see later Leonce and Lena, by Maladype). Greater participation and a more significant role can be provided for users (the audience) by inviting them to take part in the design process: this involves collaborative work. If a group of amateurs elaborates its own performance we might consider this to be user-led innovation. However, they only turn into producers by commercializing the product, thus performing to a wider public, selling tickets to an audience, or gaining other forms of subsidy for the company.

In the producer-driven model (Chesbrough 2006), the producer (the director/choreographer) acts in favor of channeling in external resources 
to the innovation activity, handles the spillovers from innovation, enhances house technology and finds/creates new markets. This model follows the path described by Schumpeter (1934), where novelties in the economy are generated by the risk-taking behavior of the entrepreneur (the producer). Firms rearrange themselves and adapt their business models to open themselves up to cooperation and raise their capabilities (Faludi 2014, with reference to Chesbrough 2006).

This process is exactly the one I identified in seeking greater understanding of how independent companies act to attract external resources: my research points towards producer-driven open innovation.

\section{The Closed Model of Innovation}

First, I illustrate the closed model. In a closed system of innovation projects enter only at one end, and come out at the other. This infers the cost of organizing innovation within the company and the cost of analyzing the market. In a closed innovation model (Chesbrough 2006, p. 3):

- research projects are launched from the science and technology base of the firm,

- progress with some projects is stopped, while some developments are reserved for further projects,

- and some go to market.

The interpretation of this model on theatrical production is the following: Elaboration of a performance is the R\&D stage. Initial research investigations might be conducted by the director/choreographer, where from a range of 'ideas' a conception arrives at the point of being worth elaboration on stage. We know that technology is a body of knowledge (Brusoni and Prencipe 2001). Thus the technological base is that of the internal knowledge of the director. The actual stage of research investigation shapes some of the 'ideas' towards conception, while others just 'fall out'. At the phase of development, internal capacities are channeled in: those working on the project (the actors, dancers, set-designers, costume designers, composers, playwrights, etc.) work within the internal innovation 'lab'. The more closed the model is, the less the ideas are challenged during the R\&D stage.

"Each play is a completely new enterprise - as it were, a new business firm organized expressly for the production of that play." (Baumol and Bowen 1968, p. 20).

Hence, a performance establishes a project-based organization, contracted and pulled together for the purpose of a project. The boundaries of the R\&D 
stage can be stretched, (e.g. with performances that involve the audience) while performance on stage may invite the audience to join in the final construction on stage, as I demonstrate later.

\section{Morgan and Freeman (Ferenc Fehér)}

I here take the example of the performance Morgan and Freeman to illustrate a closed innovation system combined with a lean production budget. Ferenc Fehér, choreographer, staged this performance, developing the conception, composing the music, choreography, and dancing himself. The project involved another person for costume design and consulting, and a further one for post-editing the musical composition and lighting. Research and development was centered around the core artist with some involvement from two other contributors. The product - the performance - went to market through the artist himself and the venue/ festival.

Opportunities to get to market (numerous festivals) are supported by lean production and touring costs. Venues (festivals) that fill their programs with 'spectacular' performances to attract a wider audience share their capacities with a number of leaner productions. Although on the one hand having a limited number of contributors to an artistic project might limit the number of 'extra' enticements that may increase an audience, on the other hand paths to market are in this case eased by the low touring and performing costs which make booking and invitations easy.

Within this one-core production scheme, communication costs are low, the number of participants in the design process is low and there is no need to share abundant information as the artist develops their conception 'from within', without interaction.

\section{It's going to get worse and worse, and worse my friend (Voetvolk)}

I draw on a further example of closed innovation based on the duality of artists. This type of performance is also constructed in a minimalist way, just like the above-mentioned one. The performance is a fluid sequence of movements performed in a one-dancer choreography, tightly knitted with the music composed. The music is constructed based on one sentence that is cut from a televangelist's speech and put into the contextual frame of the performance. The conception and the choreography was developed by Lisbeth Gruwez, and the sound, music and effects by Maarten Van Cauwneberghe. 
The inseparable integrity of music and dance is created by constant reflection on the two disciples within the simultaneous work of the two artists who broke up the sentence into basic components (words and fragments) and redesigned the architecture of intertwined music and choreography. During their work Lisbeth and Maarten played with a variety of solutions that arose from their constant interaction, where sound and movement served as an interface. The intimacy of this close collaboration was the impetus for the creation of an integrated system of meanings, created from a presumably wider set of emerging solutions. Communication costs are low in this dual scheme as well and the processes of co-creation are shared.

\section{Closed Production and Costs of Innovation}

In the first case, the core of the production is a totally closed system, relying on the construction of the architecture of meanings, while all other production tasks are considered to be the post-production phase that is informed by the core and is undertaken according to its demands. During the development phase the artist relies on the external knowledge of a consultant who is not organically integrated into the creative work.

In the second case (Voetvolk) the core consists of a dual system of meanings that merge into one in the course of the work. Post-production requires fewer tasks as the majority of them are integrated (music and sound editing) within the core production phase. The integration of capacities provides a wider set of tools with which to enter the development phase (for example, music is simultaneously constructed and does not have to be post-edited).

In both cases the close system of research and development allow for an integrated system of meanings with an architecture designed in line with the core conception. I consider the costs of innovation (Baldwin and von Hippel 2011) when analyzing the implications of innovation in a closed system. The costs of producing the good (e.g. materials and instructions) are also low, as is the creation of the design. It is also clear that the transaction costs of contracting, bargaining, control and measurement are at a minimum. However, innovation costs may rise, as creating a variety of solutions implies making greater efforts. The cost of adapting a radically new solution, which is unexpected by the audience, might exceed the benefits. In this case it might create lock-in. The repertoire of a company may involve variety, or, in contrast, act on the 'reliability' of the products that are offered, creating further lock in. 


\section{Open Innovation}

In this section, the case studies I draw on are shown to suit well the producer-driven paradigm of open innovation. Examples demonstrate that the external technology base (knowledge) might serve when developing a series of solutions at the beginning of the project. These solutions go through a selection phase when they are tested by outsiders, but they are basically selected by the main driver of innovation: the producer. The insourcing of external knowledge is an ongoing strategy during the production and elaboration of the performance (see later). Technology insourcing creates a body of knowledge shared with the newly-acquired audience or 'co-authors', thus creates new market. As a further spin off it produces a body of knowledge which serves as a basis for introducing further activities for reaching the audience. Using open innovation as a business model thus indicates the permeability of a firm (Baldwin and von Hippel 2011).

The following examples illustrate cases of powerful insourcing. Let us first review the main features of open innovation (Chesbrough 2006, p. 1-2):

1. a purposive inflow and outflow of knowledge to accelerate internal innovation,

2. expand the markets for external use of innovation

3. serve to advance technology

4. internal and external ideas are combined into architectures/ systems,

5. the aim is to create value by utilizing both internal and external ideas

6. R\&D is an open system: external and internal ideas and paths to market are both important.

\section{Maladype Company: The Process of Opening Up}

Maladype can look back on 12 years of existence now; a long path starting from its emergence as a Roma theatre engaged in societal issues to its present form as an experimental company that is exploring the possibilities of audience involvement at different stages of production. The company is following its experimental path under the flag of big 'change ${ }^{3}$ '. The turning point was marked by the staging of Leonce and Lena, which indicated the

3 The narrative frame of the change is due to an accident that the director had (which happened right in the middle of a performance). After 3 months of hospitalization he decided to introduce a totally new concept, and to realize his ideas he recruited a new cast and put on stage the play Leonce and Lena. 
beginning of the new, opening-up strategy of the company. Maladype's interpretation of Leonce and Lena consisted of an enormous variety of scenes, the sequence of which was decided upon by the audience for each occasion. Viewers were even invited to join the play during the last scene (this section of the analysis is based on a set of interviews and a press release by Vareso Aver (Maladype); manuscript Faludi 2012). Later, the analysis reveals that the search for new ways of opening up production through various levels and strategies of openness proves the power of open innovation theory.

The Maladype Company relied both on grants (by the Soros Foundation as an ethnic theatre at the beginning; while later on from the state) and private contributions. It took part in numerous cooperative international projects and has toured the world in past years. Maladype plays and holds its rehearsals and additional activities (a film club and an open academy) in a rented flat in the heart of Budapest, where the majority of their performances are held. The company thus is less tied to venues; it has its freedom to play and sell tickets directly from its own premises. This also implies a closer relationship with the audience. The physical vicinity of the viewer, who sits on a crowded bench in a room, watching and experiencing the actors running, talking, sweating, looking the viewer in the eye from very close up, creates an intimacy not experienced in a larger venue or on an elevated stage. This direct relation is reinforced by the arrangement: the actors very often play in the center of the room, moving through doors and rows of benches packed with viewers. Actors are open to chatting and talking during the breaks or at the end of the performance, as if they were in a salon. There are no back doors or a separate entrance; actors use the same bathrooms and change in a corner of a room of the flat. Money from ticket-sales goes into the company budget (it is not the venue who buys the performance from the company as in other cases), thus the relationship between the performance and targeted audience is more direct. This way of operating takes the format of a performance lifecycle that can be continued as long as there is demand, irrespective of any programming policy and independent of a given venue. The direct need to gain legitimacy and strengthen ties with the audience underlies the idea of constant involvement and the invitation for participants to engage at different stages of production, developing into an opening up strategy by the company. However, it must be said that, despite all their efforts, the company currently faces financial difficulties which are made evident by their recent call for crowdsourcing to maintain their activity. In the following I tackle the different schemes that fit into open innovation frames that are adapted in production. 


\section{Third Voice's House (The Living Picture Company) (Harmadik Hang Háza (Élőkép Társulat)/ MOME}

The Third Voice's House emerged on the basis of the Living Picture Company. The companies have defined as their goal the stretching of the boundaries of performing arts by exploring new paths and by experimenting with different conceptions through the interaction of disciplines. Self-defined as experimental, they offer a unique approach to the visual through embodying installation-like scenes with human bodies and movement. The example I draw on here involves a series of performances undertaken in partnership with the Moholy Nagy University of Arts Budapest. The collaboration covered a joint production of performances in the frame of a course entitled The Relation of Visual Communication and Performing Arts. The course was an accredited part of the curricula and a unique performing opportunity for students. The performances were bought into being with the leadership of Júlia Bársony (the course leader), evolving around one concept (text, artifact) that was provided at the beginning of the course. This scheme allowed the mining of the knowledge and skills of the students at no financial cost to the course leaders, while production costs (materials, lights, further contributors, venues) were covered by grants (for example, the National Cultural Fund). Venues in some cases provided a free space for rehearsal and performance. Six performances were created in this scheme: Tükörvilág (Sirály, 2006), Végtelen (Gödör, 2008), Ex Libris (Merlin Színház, 2008), Átjárók (Gödör, 2010), Utópia (Sirály 2011).

After examining the case of Maladype (Don Carlos, Egmont) and Third Voice's House one can conclude that the patterns of innovation of these companies fit the concept of open innovation provided by Chesbrough:

1. there is a 'purposive inflow and outflow of knowledge to accelerate internal innovation...

The case of Don Carlos (Maladype) illustrates the purposive inflow of knowledge of the German studies group (regarding Schiller, and the context of the performance).

The specialized knowledge of visual arts students (MOME) contributed not just in terms of visual design but throughout the development phase in the form of the designing of a variety of solutions. Students created and performed installations and mini-performances that were nested in the architecture of the performance. 


\section{2. and expand the markets for external use of innovation;}

students represent a new audience themselves, and have networks which may also be reached. Furthermore, they represent the next generation of audiences and critics, playing a crucial role in creating legitimacy for companies in the field of cultural production. Involvement of a (potential) audience into the development phase of the production means inviting them to create shared meaning.

\section{3. serve to advance technology;}

Taking the definition of Brusoni and Prencipe(2001) who considertechnology to be a body of knowledge, I now consider knowledge about production. In models of interdisciplinary work, external knowledge contributes to the body of knowledge used for production. In the Third Voice's House approach to creating theatre from a visual conception, the knowledge and skills of visual art students were used to stretch interdisciplinary boundaries. Their specific knowledge created a larger pool of creativity which could be tapped in respect of the technology that was used.

\section{4. internal and external ideas are combined into architectures/systems;}

Within the frames of co-creation when the producer invites in external resources (viewers, fans, the 'man on the street', students) the performance becomes an architecture of shared meaning.

5. the aim is to create value: utilizing both internal and external ideas.

Creating value from innovation means moving beyond the constant push to produce performances. External sources contribute solutions to choose from when a performance is designed. As both external and internal ideas are combined into one system, value is created through the jointly-designed architecture of meaning and the (re)combination of ideas. It seems that both companies mentioned above are following the path to creating something unique. Maladype uses newer and newer schemes of creative work, while the Third Voice's House, by following the same methodological approach, has mined out the knowledge provided by each group involved in the course.

\section{6. $R \& D$ is an open system: external and internal ideas and paths to market} are both important.

External knowledge supplies ideas that are incorporated into the architecture of the performance through co-creative work. Students serve as sources of this external knowledge, and they contribute to reaching new markets. 


\section{Open innovation is a business model.}

The examples of both Maladype and Third Voice's House show that close cooperation with groups of students was integrated into the offerings of the institution of higher education and students gained credits for their participation. In the case of Third Voice's House, students were involved in the staging and creation of the performance (elaboration of the content, preparation of installations, video work and costumes) and as performers. They were thoroughly integrated into the work and merged into a group of co-creators. Internal and external ideas are combined into a system which is unique to each specific performance, both when the audience plays an active role in staging/acting and shaping the performance, and when a partnershipbased group works using a closed system of performance.

What one can see is that both cases use an open innovation pattern for projects, whereby the organization reshapes itself in order to effectively mine out the possibilities created by open innovation. In the case of Maladype, different schemes of openness can be identified which implies constant searching to identify ways of production that focus on audience involvement.

Opening up to innovation is a process whereby open, semi-open and closed systems of innovation become strategies for companies to make use of external knowledge. To understand the opening up process in detail, I draw on the case study about Maladype, following the scheme of Barge-Gil (2010).

Table 1. Open Innovation Strategies (Following Barge-Gil, 2010: 586-7).

\begin{tabular}{|l|l|l|}
\hline Innovation & Strategy & Information sources \\
\hline Open innovators & $\begin{array}{l}\text { innovate mainly through } \\
\text { collaboration with other entities or } \\
\text { mainly by others }\end{array}$ & $\begin{array}{l}\text { At least one external source is } \\
\text { more important than the internal } \\
\text { knowledge }\end{array}$ \\
\hline Semi-open innovators & $\begin{array}{l}\text { innovate through in-house efforts, but } \\
\text { having cooperated or bought external } \\
\text { R\&D }\end{array}$ & $\begin{array}{l}\text { The most important external source } \\
\text { is as important as the internal } \\
\text { knowledge }\end{array}$ \\
\hline Closed innovators & $\begin{array}{l}\text { innovate in-house, with no } \\
\text { cooperation or external R\&D }\end{array}$ & $\begin{array}{l}\text { The most important external source } \\
\text { is less important than the internal } \\
\text { knowledge. }\end{array}$ \\
\hline
\end{tabular}

I have taken the examples used in the above-described classification from the repertoire of Maladype, applying modifications that are adapted to the specific context of theatrical production (Table 2). 


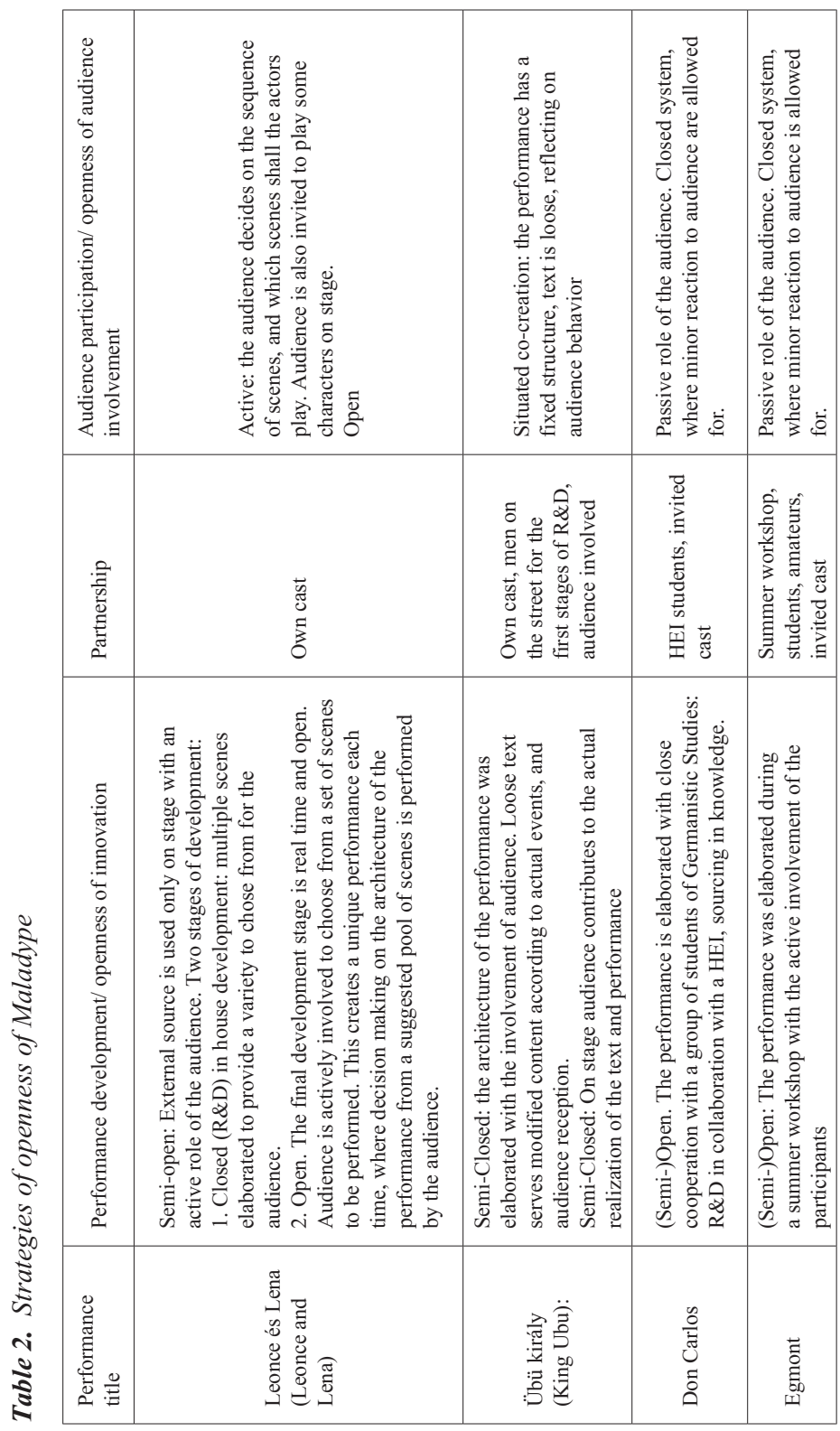


In the case of Don Carlos and Egmont an institutionalized partnership means an established contract-based form of cooperation with an institution of higher education. The pool consisted of students of German Studies who can be considered an expert group who have mastered specialized knowledge (Schiller and Goethe are the playwrights). This was an important step in knowledge sourcing, especially during the preparatory period when the participants were working on interpreting the text. It was the student group who acted out the first scenes, and it was them who first directed the actors. This method created an opportunity for sharing new visions and interpretations of the play, which were all incorporated into later work.

It is clear that in a closed system of production the audience is invited to intervene only at the final stage: on stage (Leonce and Lena). A closed collaboration scheme with external groups involved in production has a more rigid structure that does not allow for the active involvement of the audience in the end (Don Carlos).

These are examples of producer-driven innovation, as the locus of innovation is the collaborative group where the director (producer) plays the roles of coordination and decision-making. Furthermore, the invitation to participate in the 'group' and the concept for this work were initiated by the director.

\section{Audience-Development through Open Creation Process (R\&D)}

The following is an illustration of how opening up the process of creation serves as a valuable tool for audience development and the establishment of ties:

"...it was Leonce and Lena when the audience turned to us and started to love us again. There was a segment of viewers who were with us tightly even before that, but later it became extended. Nowadays, well, we have a constant... audience, especially due to the rehearsal process for King Ubu, which was completely open. They came every evening and stayed for hours, participating actively, the new audience segment emerged then, and since then has followed our work". (February 2012, Actress)

The open rehearsals of King $U b u$ developed into a real collaborative experience, expanding group boundaries. The audience was fully involved on a voluntary basis in elaborating the scenes and participating in the games and drills. This method of work is similar to open collaborative innovation 
(when the output is a public good, and contributors do not commercialize the product: Baldwin, von Hippel 2011), with an important constraint: the innovation output is sold: participating users turn into viewers who buy tickets to see the performance.

"the whole performance was created together with the viewers, as, after a while, it was not like rehearsing in front of the audience but as if the company consisted of not eight or four actors (four of us act in Übü), but forty people working together." (Actor, May 2012)

This implies that a co-creative group has been formed through the intimacy of acting and creating. I coin the term 'open creation process' to describe this phenomenon, as viewers contribute voluntarily without commercializing the product. The creation process thus is open, but lead by a producer, with no public good emerging as a result (which makes this approach distinct from the open collaborative innovation approach that is viable in open source development).

\section{Testing solutions to improve design}

Audience involvement in the process of creation can be a strategy for testing elements of performance within the elaboration process of the performance, rather than a tool for directly developing an audience. The locus of innovation is still the producer. It is a tool for choosing from a set of solutions at a given stage of product development. The audience's motivation is to take a look at rehearsals.

"While rehearsing a scene we often went to Mikszáth square and invited people on the street to come in and see us, if they had the time. We did that during [the time we were working on] Don Carlos and Platonov. Actually, the man on the street, if he had the will, could come up and see it, and give feedback about whether what we were doing was understandable" (Actor, May 2012)

"Once they played the first five scenes of Don Carlos, and we had to direct them. We watched 5 variations [because] we were split into 5 groups. And then you watch 5 different variations, and find out which one works out the best." (Actor, February 2012). 
In addition to testing, this example illustrates the fact that increasing the number of individuals and groups involved in elaboration of a performance raises the number of design options to choose from in the search for the best.

Openness: From Outbound Toward Inbound Innovation

The examples above prove that 'revealing' is a reliable strategy for obtaining wider markets for commercializing innovations; this is also in-line with findings from manufacturing sectors. However, it is also known that along with benefits there are also costs to being open. Firms reveal themselves to a different extent and openness indicates a state of being in between the bipolar notions of open and closed (Dahlander and Gann 2010).

Based on Chesbrough et al. (2006) - and also tackled by van de Vrande et al. (2009) and Chiaroni et al. (2011) - Dahlander and Gann (2010) elaborated two types of open innovation, both relying on (non-)pecuniary processes:

inbound or outside-in open innovation, where firms open up to using external resources "for improving the firm's innovation performance"

outbound or inside-out open innovation, which is aimed at "commercially exploit[ing] innovation opportunities" of firms better-suited to commercializing a given technology (p. 35).

Analyzing empirical findings about revealing, selling, sourcing and acquiring resources for innovation, Dahlander and Gann (2010) conclude that the benefits and disadvantages of openness play different roles for different firms. They typify extents and forms of openness through their understanding of firms' strategies of revealing. The examples I present here illustrate that strategies of openness differ from project-to-project. I rely on further examples in addition to Maladype's production from the world of contemporary theatre and dance companies and artists. I have not presented these cases in detail although they prove that both the pecuniary and nonpecuniary form of inbound and outbound openness can reliably be said to exist in this peculiar field. 
Table 3. Open Innovation (Following Dahlander and Gann, 2010).

\begin{tabular}{|c|c|}
\hline Type of openness & Definition/ Example \\
\hline $\begin{array}{l}\text { Revealing. Outbound } \\
\text { innovation: non-pecuniary }\end{array}$ & $\begin{array}{l}\text { How internal resources are revealed to the external environment } \\
\text { without immediate financial rewards, seeking indirect benefits to the } \\
\text { focal firm. }\end{array}$ \\
\hline Performing arts & $\begin{array}{l}\text { The revelation of a new performance before the premier serves for } \\
\text { raising awareness and testing. } \\
\text { E.g. revealing during the work-in-progress. Testing the solutions on } \\
\text { the man on the street (Don Carlos). Work-in-progress presentations } \\
\text { organized in venues or labs (Wokshop Foundation). }\end{array}$ \\
\hline $\begin{array}{l}\text { Selling. Outbound innovation: } \\
\text { pecuniary. }\end{array}$ & $\begin{array}{l}\text { How firms commercialize their inventions and technologies through } \\
\text { selling or licensing out resources developed in other organizations. }\end{array}$ \\
\hline $\begin{array}{l}\text { Contemporary dance and } \\
\text { software development }\end{array}$ & $\begin{array}{l}\text { The company commercializes its knowledge gained through its } \\
\text { production and staging at events: for eg. Free Academy (organized } \\
\text { by Maladype), which is an open discussion moderated by the director } \\
\text { with invited guests and actors. Participants pay entrance fees. The } \\
\text { director organized film clubs with moderated discussions after } \\
\text { screenings. These screenings and discussions are in line with the } \\
\text { performances produced by the company. It is a tool for strengthening } \\
\text { the ties with the audience, and involving it for further participation, } \\
\text { through improving understanding of the artistic expression of the } \\
\text { company. } \\
\text { Commercializing the technical knowledge of professional dancers. } \\
\text { E.g. for software development based on sensors detecting movements } \\
\text { (Animata with Gabor Pap, and a rehabilitation software developed by } \\
\text { Kata Juhasz). }\end{array}$ \\
\hline $\begin{array}{l}\text { Sourcing. } \\
\text { Inbound innovation: non- } \\
\text { pecuniary. }\end{array}$ & $\begin{array}{l}\text { How firms can use external sources of innovation. Firms scan the } \\
\text { environment prior to initiating internal R\&D for existing ideas and } \\
\text { technologies. If available, firms use them. Accounts of corporate } \\
\text { R\&D labs are vehicles for absorbing external ideas and mechanisms } \\
\text { to assess, internalize and make them fit with internal processes. }\end{array}$ \\
\hline $\begin{array}{l}\text { Performing arts } \\
\text { dance }\end{array}$ & $\begin{array}{l}\text { If new modules are entered into the architecture of the (new) } \\
\text { performance: artists scan other performances and even artifacts of } \\
\text { other disciplines to gain ideas from. The absorptive capacity of the } \\
\text { artist allows for incorporating external ideas and practices into her } \\
\text { own artistic activity. For e.g. in dance that might mean the ability } \\
\text { to reproduce a sequence of movements, or on process level: some } \\
\text { specific arrangements. These might be pure imitations, but even } \\
\text { inspirations where ideas generate further ideas and get incorporated } \\
\text { into a peculiar system of ideas. This later can be considered as } \\
\text { innovation based on incorporation. Solutions adapted by companies/ } \\
\text { artists. }\end{array}$ \\
\hline $\begin{array}{l}\text { Acquiring. Inbound innovation: } \\
\text { Pecuniary. }\end{array}$ & $\begin{array}{l}\text { Firms acquire input to the innovation process through the market } \\
\text { place. Openness here is how firms license-in and acquire expertise } \\
\text { from outside. }\end{array}$ \\
\hline Project-based-organization & $\begin{array}{l}\text { Expertise acquired from outside becomes part of the co-creating } \\
\text { group. The need for external expertise in favor of boosting } \\
\text { innovativeness in production pushes toward collaboration, which is } \\
\text { more typical for funded joint projects, or interdisciplinary projects. }\end{array}$ \\
\hline
\end{tabular}




\section{CONCLUSIONS}

Independent companies involved in theatrical and dance productions offer variety while sharing largely the same field of stakeholders and audiences. Performances compete for venues and viewers and serve as an interface for gaining legitimacy in the field. Audience involvement and participative forms of staging are not new to theatrical productions. In this paper I aimed to help the reader understand the strategic use of external knowledge brought in by students, the audience, workshop-participants, or simply just the man-on-thestreet as a tool for innovation and a survival strategy. In searching for answers to the originally-defined research questions (1. how exactly do companies make use of external knowledge while developing their new performances? and, 2. how does sourcing in evolve into a strategy?) I reached out to find examples that could be neatly fitted into models of open innovation.

First, I examined two examples of a closed system of innovation. I highlighted the difference between a one and a dual core of production: the latter creates a favorable climate for creating an architecture of meanings based on the interaction of disciples through intimacy.

We learned from the examples that an audience can serve as a source of external knowledge at different stages of production: research, development, testing and finally, production on stage. The development of a performance involves different stages, starting from exploring the scenes and the original conception to the fine-tuning of the dialogues/staging, depending on the working method of a given director. Examples of Maladype's approach to production show that the notions of open, semi-open and closed development (following Barge-Gil's frame 2010) are viable as frames for understanding theatrical production (depending on the extent the audience is involved). Furthermore, the case study of Maladype sheds light on some of the determining factors that pulled the company toward using extended forms of production. The example of Maladype exposed the fact that, on the one hand, opening up relies on the intimacy of performances through the creation of a direct relationship with the creators/performers and audience. On the other hand, opening towards new markets and sources of renewal based on the direct involvement of 'consumers' may be a strategy for overcoming uncertainty. The purposeful creation of variation concerning how external knowledge can be pulled in and mined, as well as how spillovers of the body of knowledge gained through production can be commercialized, puts Maladype on the shelf of companies/firms who are adopting and adapting to open innovation. That said, it can be concluded that Maladype follows a path of openness as a business model. 
By identifying the locus of innovation and the related transactions one can classify the given patterns as 1 . user-driven; 2 . producer-driven; and/or, 3 . collaborative innovation. As this paper explored producer-driven examples, I coined the term 'open creation process' to describe a process of co-creation where free and voluntary contributions are welcomed without constraints, while the result is a commercialized good (not a public good, as in the forms of open collaborative innovation). The examples tackled illustrate how pulling in external knowledge serves to increase variety and assists with the developing of solutions, the mining out of additional skills, testing (to improve the design of innovation), extending the market and gaining legitimacy for the field. Furthermore, the case studies pointed to the fact that differing strategies exist concerning openness and revealing from project-to-project. I adapted the frame of outbound and inbound innovation following Dahlander and Gann (2010), drawing on the peculiarities of performing arts production and supporting the model with examples. This effort can serve as a starting point for further research, which will improve understanding of company characteristics and behavior. The limitation of this analysis relates to the nature of the explorative approach to mapping patterns and bringing them in line with the available models of interpretation of open innovation strategies. Using a wider sample of companies backed by quantitative analysis and theoretically modeling the costs of openness in artistic production would add valuable insight into understanding the precise determinants of innovation strategies.

\section{REFERENCES}

Aitamurto, Tanja - Lewis Seth C. (2012), "Open Innovation in Digital Journalism. Examining the Impact of Open APIs at Four News Organizations" New Media and Society, Vol. 15, No. 2, pp. 314-331.

Bakhshi, Hasan - Throsby, David (2010), Culture of Innovation. An Economic Analysis of Innovation in Arts and Cultural Organizations, National Endowment for Science, Technology and the Arts (NESTA) Research report, June 2010.

Baldwin, Carliss Y. - von Hippel, Eric (2011), "Modeling a Paradigm Shift. From Producer Innovation to User and Open Collaborative Innovation" Organization Science, Vol. 22, No. 6, pp. 1399-1417.

Barge-Gil, Andres (2010), "Open, Semi-Open and Closed Innovators. Towards an Explanation of Degree of Openness", Industry and Innovation, Vol.17, No.6, pp. $577-607$

Besharov, Gregory (2005), “The Outbreak of the Cost Disease: Baumol and Bowen's Founding of Cultural Economics" History of Political Economy, Vol. 37, No. 3, 
pp. 413-430.

Baumol William J. - Bowen William G. (1968), Performing arts. The Economic Dilemma, New York, The Twentieth Century Fund

Becker, Howard S. (1982), Art Worlds, University of California Press

Bourdieu, Pierre (1993), The Field of Cultural Production. Essays on Art and Literature, ed. and intr. by Johnson R., Cambridge, Polity Press

Camarero Carmen - Gorrido, M. Jose - Vicente, Eva (2011), "How Cultural Organizations' Size and Funding Influence Innovation and Performance. The Case of Museums", Journal of Cultural Economics, Vol. 35, No. 4, pp. 247-266.

https://ideas.repec.org/a/kap/jculte/v35y2011i4p247-266.html

Caves, Richard E. (2000), Contracts Between Art and Commerce, Harvard University Press, retrieved from google books

Cowen, Tyler - Grier, Robin (1996), "Do Artists Suffer from a Cost-disease?" Rationality and Society, Vol. 8, No. 1, pp. 5-24.

Chesbrough, Henry (2006), "Open Innovation. A New Paradigm for Understanding Industrial Innovation”, in: Chesbrough H., Vanhaverbeke Wim, West, Joel ed. Open Innovation. Researching a New Paradigm, Oxford University Press, pp. 1-14.

Chesbrough, Henry (2011), Open Services Innovation. Rethinking Your Business to Grow and Compete in a New Era, Jossey-Bass

Chesbrough, Henry - Crowther, Adrienne Kardon (2006), "Beyond High-Tech. Early Adopters of Open Innovation in Other Industries", R\&D Management, Vol. 36, No. 3, pp. 229-236

Barge-Gil (2010), “Open, Semi-Open and Closed Innovators. Towards an Explanation of Degree of Openness", Industry and Innovation Vol. 17, No. 6, pp. 577-607. http://dx.doi.org/10.1080/13662716.2010.530839

Chiaroni, D. - Chiesa, Vittorio - Frattini F. (2011), “The Open Innovation Journey. How Firms Dynamically Implement the Emerging Innovation Management Paradigm", Technovation, special issue on Open Innovation, Vol. 31, pp. 34-43

Cohen, Wesley M. - Levinthal, Daniel A. (1990), “Absorptive Capacity. A New Perspective on Learning and Innovation", Administrative Science Quarterly, Vol. 35 No.1, pp. 128-152.

Dahlander, Linus - Gann, David M. (2010), "How Open is Innovation", Research Policy, Vol. 39, No. 6, pp. 699-709

Dell'Era, Claudio (2010), “Art for Business. Creating Competitive Advantage through Cultural Projects", Industry and Innovation Vol. 17, No. 1, pp. 71-89.

DiMaggio, Paul - Sternberg, K. (1985), "Why do some theatres innovate more than others? An empirical analysis", Poetics Vol. 14, No. 1-2, pp. 108-122.

DiMaggio, Paul - Mukhtar, Toquir (2004), “Arts Participation as Cultural Capital in the United States, 1982-2002. Signs of Decline?”, Poetics, No. 32, pp. 169-194.

Faludi, Julianna (2014), "From Open Toward User and Open Collaborative Forms of Innovation", Budapest Management Review, Vol. 45, No. 11, pp. 33-43.

Faludi, Julianna (2012), Vareso Aver and Maladype, manuscript

Grabher, Grenot (2002), "The Project Ecology of Advertising. Tasks, Talents and 
Teams", in: Grabher, G. ed. Production in projects: Economic geographies of temporary collaboration. Regional Studies Special Issue Vol. 36, No.3, pp. 245263.

Grabher, Grenot (2004a), "Temporary architectures of learning: knowledge governance in project ecologies”, Organization Studies, Vol. 25, No. 9, pp. 1491-1514.

Grabher, Grenot (2004b), "Learning in Projects? Remembering in Networks", European Urban and Regional Studies, Vol. 11, No. 2, pp. 103-123.

Hansmann, Henry B. (1980), "The Role of Nonprofit Enterprise", The Yale Law Journal, Vol. 89, No. 5, pp. 835-901.

Hansmann, Henry B. (1981), "Nonprofit Enterprise in the Performing arts", The Bell Journal of Economics, Vol. 12, No. 2, pp. 341-361.

Hauge, Atle - Hracs, Brian J. (2010), "See the Sound, Hear the Style. Collaborative Linkages Between Indie Musicians and Fashion Designers in Local Scenes", Industry and Innovation Vol. 17, No. 1, pp. 113-129.

Hirsch, Paul M. (2000), “Cultural Industries Revisited”, Organization Science Vol. 11, No. 3, pp. 356-361.

Hirsch, Paul M. (1972), "Processing fads and fashions: An organization-set analysis of cultural industry systems", American Journal of Sociology No. 77, pp. 639-659.

Lange Bastian - Kalandides Ares - Stöber Birgit - Mieg H.A. (2008), "Berlin's Creative Industries. Governing Creativity?", Industry and Innovation, Vol. 15, No. 5, pp. 531-548. http://dx.doi.org/10.1080/13662710802373981

Last, Anne-Kathrin - Wetzel, Heike (2011), "Baumol's Cost Disease, Efficiency and Productivity in German Public Theatres", Journal of Cultural Economics, Vol. 35, No. 3, pp. 185-201. http://link.springer.com/article/10.1007/s10824-011-9143-5/ fulltext.html

Lewis, Seth C. - Usher, Nikki (2013), "Open Source and Journalism. Toward New Frameworks for Imagining News Innovation", Media, Culture and Society, Vol. 35, No. 5, pp. 602-619.

Peterson, R. A. (2000), “Two Ways Culture is Produced”, Poetics, Vol. 28, No. 2-3, pp. 225-233. http://www.sciencedirect.com/science/article/pii/S0304422X00000231

Potts, Jason D. - Hartley, John - Banks, John A. - Burgess, Jean A. - Cobcroft, Rachel S. - Cunningham, Stuart D. - Montgomery, Lucy (2008), "Consumer Co-creation and Situated Creativity", Industry and Innovation, Vol. 15, No. 5, pp. 459-474. DOI 10.1080/13662710802373783

Ritchie, Jane - Lewis, Jane (2010), Qualitative Research Practice. London: Sage, Chapter 1: The Foundations of Qualitative Research, pp. 1-23.

Schumpeter, Joseph A., (1934 (1961)), The Theory of Economic Development, New York, Oxford University Press

Sedita, Silvia R. (2008), "Interpersonal and Inter-Organizational Networks in the Performing Arts. The Case of Project-Based Organizations in the Live Music Industry", Industry and Innovation, Vol. 15, No. 5, pp. 493-511 DOI $10.1080 / 13662710802373833$

Siggelkow, Nicolaj (2007), "Persuasion with case studies", Academy of Management Journal, Vol. 50, No. 1, pp. 20-24. 
Staber, Udo (2008), "Network Evolution in Cultural Industries", Industry and Innovation, Vol. 15, No. 5, pp. 569-578. DOI 10.1080/13662710802374229

Stake, Robert E. (2003), “Case Studies”, in Norman K. Denzin, Yvonna S. Lincoln ed:

Strategies of Qualitative Inquiry, Sage Publications, US, 2nd ed., 134-164

Throsby, C. David - Withers, Glenn A. (1979), (reprinted in 1993), "The Economics of the Performing arts", in Gregg Revivals ed: Modern Revivals in Economics, Hampshire

Van de Vrande - Vareska, de Jong - Jeroen P.G. - Vanhaverbeke Wim - de Rochemont, Maurice (2009), "Open Innovation in SMEs. Trends, Motives and Management Challenges", Technovation, Vol. 29, No. 6-7, pp. 423-437.

http:/www.sciencedirect.com/science/article/pii/S0166497208001314

von Hippel, Eric (1976), “The Dominant Role of Users in the Scientific Instrument Innovation Process", Research Policy, Vol. 5, pp. 212-239.

von Hippel, Eric (1988), The Sources of Innovation, Oxford University Press, New York

von Hippel, Eric (2005), Democritizing Innovation, The MIT Press, Cambridge, Massachusetts 